\title{
The Natyashastra-based analysis of Mahesh Dattani's Where Did I Leave My Purdah
}

\author{
Mrunal Chavda \\ Assistant Professor, Institute of Language Studies and Applied Social Sciences. ORCID: \\ oooo-0o02-3817-4124. Email: mrunalchavdaiima@gmail.com,
}

\begin{abstract}
This article uses the Natyashastra, an Indian treatise on performing arts, to develop an overlooked method of theatrical analysis. This treatise offers useful insights on how gestures are produced during the performance, which has been practiced by performers across the world. While scholars research the Natyashastra in the contexts such as theatre, rasa theory, and its bodymind connection, this treatise has been employed to analyze gestures produced by contemporary Indian theatre performers in Mahesh Dattani's Where Did I Leave My Purdah. The outlined exercise through an examination of a case study advocates a method of theatrical analysis.
\end{abstract}

Keywords: production analysis, Mahesh Dattani, Indian theatre in English, Natyashastra.

\section{Where Did I Leave My Purdah: The Narratives}

In 2013, the Prime Time Theatre Company (Mumbai) produced Mahesh Dattani's ${ }^{\mathrm{i}}$ Purdah. Lillette Dubey ${ }^{\text {ii }}$, the artistic director, toured the production across Indian cities including Pune. Five actors performed seven scenes in eighty-five minutes. The Purdah connects the audience to India's Sanskritic theatrical history through Kalidasa's Abhijnansakuntala, ${ }^{\text {iii }}$ India's dreadful experience of partition in $1947^{\mathrm{iv}}$, and a Bollywood anecdote on the life of actor-dancer Zohra Sehgal's (1912-2014). ${ }^{\mathrm{V}}$ These three narratives control the lives of the protagonist Nazia Shahiba and her loved ones.

Nazia performs Shakuntala from Kalidasa's Abhijnanshakuntala in Lahore (prepartition India). While performing, she and her sister. Zarina and her husband, Suhel escapes to New Delhi to save their lives from the partition rioters. Unfortunately, rioters kill Zarina and rape Nazia on the train. During this catastrophic event, Suhel, Nazia's husband, does not appear anywhere in the scene and therefore, his whereabouts and his inaction can be questioned as he could have possibly attempted to save Zarine and Nazia which did not occur, and his absence creates suspicion. Nazia's unpleasant incident of migration from Pakistan to India haunts her, and so, Nazia chooses amnesia. With incidents such as riots, killing, and rape, the Purdah rouses sentiments such as love, hate, and tragedy. This article focuses on the manifestation of three feelings such as love, tragic and laughter. This article employs the Natyashastra descriptors to demonstrate to examine the manifestation of three key emotions elicited by the production. Before

\footnotetext{
(c) AesthetixMS 2020. This Open Access article is published under a Creative Commons Attribution Non-Commercial 4.o International License (http://creativecommons.org/licenses/by-nc/4.o/), which permits non-commercial re-use, distribution, and reproduction in any medium, provided the original work is properly cited. For citation use the DOI. For commercial re-use, please contact editor@rupkatha.com.
} 
discussing the descriptions, however, a brief background on the Natyashastra, rasa, and bhava would prove beneficial.

\section{Natyashastra, Rasa-bhava, and Abhinaya}

While scholars on the Natyashastra discuss and employ rasa and bhava to devise performance training and delivery, this essay investigates their critical application in a live performance setting to examine the congruity between actors' mental states, physical manifestation, and the performed texts. Scholarly evidence such as Nair (2015), Madhavan (2010) and Schechner (2015) suggests that the Natyashastra, despite its antiquity, remains contemporaneous. Rooted in Vedas (Dhavan \& Reddy, 2004, p. 4), the thirty-six chapters of the Natyashastra, written between ' 200 BCE and 200 CE' (Zarrilli P. , Kathakali DanceDrama: Where Gods and Demons Come to Play, 2000, p. 107), instruct interrelated branches of performing arts such as drama, dance, and diction. Although Schwartz situates Natyashastra with Hindu ritualistic traditions (Schwartz, 2008, pp. 1-3, 14-20), Srinivas favors its "colossal work on dramatic art and technique" (Srinivas, 2014, p. 29) and advances multiple interpretations of the Natyashastra in different contexts with manifold layers of meaning. It supplies highly codified gestural language and interlinks it with performative text as Barlingay identified the treatise offering the language of staging (Barlingay, 1981, p. 442). These are entwined with embedded concepts of rasa and bhava, which form rasa theory. ${ }^{\text {vi }}$ Bharata enumerates the concept of rasa and bhava in Chapter Six and Seven of the Natyashastra.

Generally, the terms rasa and bhava have been rendered as taste and mental states respectively. In the rasasutra (statement of rasa), Bharata explains his three-part definition: "Rasa is the cumulative result of vibhava (stimulus), anubhava (involuntary reaction) and vyabhicaribhavas (voluntary reaction)." The combination of these constituents allows spectators to experience the rasa, which Nair suggests presents "a theory of mimetic communication" (Nair, Rasa Theory and Neural Mechanism, 2012, p. 3). This process of communication becomes clearer when uses Patrick Hogan clarification of these two concepts: 'Bhava is, roughly, what the characters are supposed to be feeling. Rasa is what the spectator is feeling' (Hogan, 2003, p. 39). In short, bhavas as ingredients of cooked food develops a particular rasa (taste) within spectators despite elements having their unique flavor, which Bharata likens to acting (abhinaya) (Zarrilli P. , Introduction: Acting as Psychophysical Phenomenon and Process, 2013, p. 255).

The process of acting involves factors such as actor training methods, culture and language, and gender. When actors perform, they retain their uniqueness and merge it with others,' creating a new taste. These exchanges happen due to bhava and rasa. This process, according to Richard Schechner, results in acting or abhinaya where performers bring spectators closer to the characters they perform through their bodymind (Schechner, Rasaesthetics, 2001). 
Phillip Zarrilli suggests that actors engage their body and mind in absorbing the mental states (or bhavas) of the characters they perform. By enacting given characters, actors' bodies react by "doing" or "being" the character. Zarrilli elucidates this process as "absorption" (Zarrilli P. , Introduction: Acting as Psychophysical Phenomenon and Process, 2013, p. 255). Additionally, actors synchronize their bodymind, text, and music, (Zarrilli P. , Imperial Theatre: Pleasure, Power and Aesthetics, 2006, pp. 86-87) which engages actors' bodymind completely (ibid., 90) through regular improvisation by exploring hidden bhavas lying latent within themselves. Such a performance could be achieved, as Arya Madhavan suggests, when "the concentration of body and mind is focused on rasa" (Madhavan, 2010, p. 207). Actors attain characters' states of mind through their body, or to put it simply, they act and perform effectively due to the strong connection and control between their body and mind. Zarrilli defines this as a psychophysical phenomenon and an "embodied process and practice present in actors' bodymind" (Zarrilli P. , Introduction: Acting as Psychophysical Phenomenon and Process, 2013, p. 41). Furthermore, Daboo (2013) maintains that these psychophysiological processes create "precise scores of action, breath, gestures, an image that creates the embodied presence of a character in a given moment of the performance" (Daboo, 2013, p. 260). In short, the articulation and the manifestation of the feelings are processed through neural mechanisms, which are realized through physical organs. This progression of an exhibition of feelings from mind to body can be investigated using Bharata's descriptors of rasa and bhava.

While actors focus on the emotion to be manifested through bhavas, spectators' minds produce and enact those bhavas simultaneously within themselves based on their creative capabilities, which result in tasting a specific rasa. Such transmission of bhavas and rasa from actors' bodymind to spectators relates to Bharata's notion of acting or abhinaya. In other words, rasa is mutual co-creation that occurs due to an audience-actor relationship where "actions are immediately understood without explicit awareness" (Committeri \& Chiara, 2016, p. 33). Here, it is useful to know that bhavas do not produce rasas directly, but audience members embody the rasa through a process of active, responsive engagement with the rasas. In other words, they attempt to decode what actors have encoded through their bodymind.

This essay investigates a possibility to notate micro gestures and their relation to the mental states when actors are not trained in the Natyashastra tradition of acting that Daboo outlines. Integral to this analysis is a cross-sectional comparison with other models such as Pavis' mise-en-scene. Further, using actor interviews, this analysis examines how various factors such as actor training helps them to perform mental states of characters and physicalization of these states. Finally, this article explores how the Natyashastra can be used to examine actors' gestures and their connections to their mental states.

In 2015, two exceptional studies dealt with performance analysis using the Natyashastra. First, Chandrika Patel triangulated her analysis of Pavis' mise-en-scene, Brecht's Gestus and Bharata's Natyashastra to examine British South Asian theatres (Patel, 2015) though she applies rasa terminologies, the micro-gestures and its relation to 
the acting need further input. Second, examining Akram Khan's dance performances, Royona Mitra commented that Khan translates and mutates abhinaya for his eclectic audiences' (Mitra, 2015, p. 156). These two scholarly investigations aimed to document innovative practices by British South Asian performers, dance and drama. Mitra's descriptive analysis of Khan's performances traced rasa and bhava extensively. Thus, these studies suggest a broad interest to use the treatise to apply to drama and dance.

Although scholars such as Richard Schechner, David Mason, and Kapila Vatsyayan advocated the study of the Natyshastra to understand the performances, the concentration remains on the treatise rather than an application from it. Nevertheless, Schechner's rasaboxes exercise invited scholarly attention in the works by Minnick, Nuttal, and Neuerburg-Denver. ${ }^{\text {vii }}$ Their research focuses on developing performer practice rather than devising an analysis tool to examine theatre for critics with which actors' delivery (i.e., gestures) can be investigated and not the text as Gantar (1996) proposed to examine. ${ }^{\text {viii }}$ Extending Gantar's idea, this article draws its argument from Schechner's concept of mood and play framing. Useful here is his suggestion that humans are skilled in recognizing the experience of play since mood 'can be read by someone skilled in understanding body languages, gestures, and facial displays' (Schechner, Performance Theory, 2005, p. 97). ${ }^{\text {ix }}$ This article, thus, locates inadequate studies on the Natyashastra to examine theatre performances by focusing on actors' gestures. Hence, it fills this lacuna by testing the treatise to develop a production analysis method in the context of contemporary Indian theatre in English.

\section{Bharata's Natyashastra-based production analysis: Proposed Method}

This article extracts physical descriptors of each rasa and examines five selected rasas. Organizing them in a table, the actors' physical manifestation of this rasa is noted. The micro gestures are then compared with what processes the actors underwent while performing relevant states of mind. In other words, they were interviewed to understand what went when they were 'doing/being' a character. The idea of conducting interviews with actors, directors, and the playwright emerged due to the need to identify the relationship among them and how that helps to enact their mental states and their influence on each other. While sharing notations of analysis during the interviews, this resulted in a discussion on abhinaya (acting).

Interviews of the actors, director, and playwright revealed, first, that none of them had trained in the Natyashastra. To begin with, Lillete Dubey, trained by Barry John, played the character of Nazia. Soni Razdan, who depicted Ruby and Zarina, taught at the Guildhall School of Music and Dance in London. Neha Dubey, who played three characters-- Shakuntala, young Nazia, and Nikhat, Ruby's daughter-- is a trained psychotherapist and not a professionally trained actor; however, she has acted in many Hindi and English films and theatre. Similarly, Sid Makkar performed three characters: Vinay, Suhel, and Dushyant. Although he studied in the United States, he is not a professionally trained actor (Taneja, 2009). Likewise, Priyanka Karunakaran also portrayed three characters: a young actor, Gautami, and Ansuya. As a video jockey and a 
fashion model, Ms. Karunakaran works in the theatre to survive in Mumbai. This information signifies that actors' manifestation of emotions through micro gestures and their actor training might not relate to each other directly. This background on actors' training shall become clearer when different rasa and bhava descriptors are examined in detail. This article uses the three-part definition of rasa as discussed earlier to investigate display of actors' micro gestures.

\section{Love or Sringararasa}

The erotic rasa is manifested 'through a series of physical and mental properties' (Nair, Rasa Theory and Neural Mechanism, 2012) in Purdah. Suhel and Nazia perform the famous love scene (Image 1 below) between Dushyant and Shakuntala from Kalidas' Abhinjanshakuntala. The scene was performed when Nazia was young and lived in Delhi in 1952.

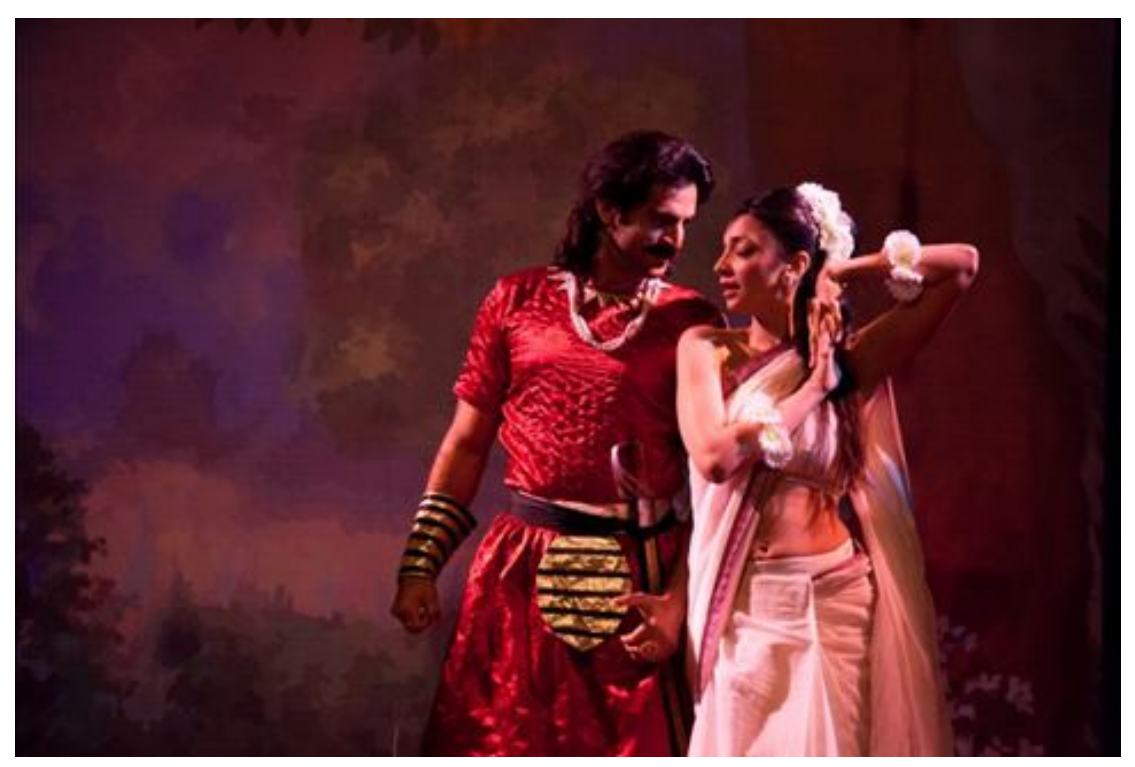

Figure 1: Dushyant's romance with Shakuntala. Photograph Courtesy (c) Prime Time Theatre Company, Mumbai ${ }^{x}$

The vibhavas (determinants) required for this rasa to occur are the pleasant season, garlands, people near and dear ones, ornaments, sensual objects, unguents, going to the garden, objects of pleasure, experiencing pleasure, listening to sweet voices, seeing beautiful things and play sports. Shakuntala visits a bank of the river with her friends, Ansuaya and Priyambada to fetch water. While she enjoys the morning weather as she sings a song, the honeybee disturbs her. The physical presence of flowery ornaments on Shakuntala's body, the fragrance from the flowers and the morning ambiance stimulates the growth of the pleasant environment, a favorable atmosphere for the growth of love. While she sings and later complains about the creature, the King Dushyant listens to her 
sweet voice, watches Shakuntala. The killing of the bee provides a pleasant experience as the king removes an obstacle for Shakuntala's sake.

Regarding Consequents (anubhava), Bharata lists clever and significant glances of the eyes, movements of the eyebrows, ogling looks, movement of limbs, sweet major dance figures. Shakuntala's beauty is unmatchable, and her physique resembles a dancing figure. While honey-bee disturbed her and later her encounter with the king, Neha Dubey could be seen performing lalita glance (sweet, contracted at the end of the eyes, smiling, and movement of eyes) and nihancita head gesture (two shoulders raised with the neck bent on one side). Along with her prasanna (pleasant) face, she manifests gestures such as utksepa (raising the eyebrows), visarga (spreading out of lips), udvahi (mouth turned up). On the other hand, Dushyant's facial expressions could correspond with prasanna (pleasant) face, nata (face bent down), and gestures such as phulla (cheeks are raised) and visarga (spreading out the lips).

Finally, Bharata lists all the transitory states (vyabhicaribhavas) except fright, lethargy, ferocity, disgust. Shakuntala displayed restlessness, sweat, trembling, and choking of the voice due to honeybee harassment. While honeybee annoys Shakuntala, Dushyant feels envy of this little creature and spontaneously removes the insect with energetic enthusiasm and excitement to meet Shakuntala.

\section{Hasyarasa (laughter)}

Bharata states that hasyarasa can be performed through limbs, dress, and actions. The comedy occurs at some places in the Purdah. Nazia, at eighty, plays a prank on coworkers as an old actor. In Scene 1, Nazia bets that Vinay, the assistant director for the film she works in, would kiss her. Nazia waits for Vinay in her vanity room. As he enters to escort her on the set, she faints. Anxious Vinay provides mouth-to-mouth resuscitation to Nazia and Nazia considers this first-aid treatment as a kiss and announces herself as the winner of the bet.

Here, three actions with limbs create a comic scene. First, Nazia acts as if she fainted. She does this sthambha (paralysis) temperamental state by sama (lying down) posture. This pose is accompanied by two gestures namely, abhugna (the breast lowered, back high, shoulders slightly bent and at times lose) udvahita (the breast raised). Secondly, Vinay's resuscitation is performed with purna belly and nata shank gesture (the knee bent). Finally, Nazia manifested her joy through hrsta glance (moving, slightly bent, eyeballs not wholly visible winks), and prasarita gesture with sides (the stretching of the side in their direction).

Additionally, she exhibits nihancita head gesture (two shoulders raised with the neck bent on one side), kuncita eyebrows (slightly bending of eyebrows one by one), vikunita (contracted nose) and purna cheek gestures (full-blown cheeks). Although this play has been popularly labeled as a comedy, there are other dominant rasas as well for example, pathetic, terrible and anger. 


\section{Karuna (Pathetic)}

Karunarasa results from grief, death, and the loss of a beloved. Suhel abandoned Nazia, similar to Dushyant deserted Shakuntala, and called her after fifty years. When he is on the deathbed, he asked for forgiveness before his death. This call from Suhel brought Nazia's past alive. Perturbed with such news, Nazia is paralyzed, performed with sthambha temperamental state. Her thigh movements are suspended, and she exhibited sranta glance (eyelids down due to fatigue, narrowed corners of the eyes, fallen eyeballs). While listening to Suhel's death, she manifested nihancita head gesture (two shoulders raised with the neck bent on one side) along with baffled touch to her samudgaka lips (contracting lips and at rest). Her love and affection toward Suhel reflects in her khalva belly (depressed, bent) and sobbing. Her shaky voice with glances such as dina (lowered eyelid slightly fallen, eyeballs slightly swollen and moving very slowly), karuna (upper eyelids descend and eyeballs at rest) and dhuta head gesture (slow movement of the head) confirm her plead Suhel to return to own life. Moreover, she displayed ksama cheek gesture (fallen cheeks, depressed), rakta face (reddened face) and vivrta mouth gesture (the mouth with the lips kept apart).

Furthermore, her ayata posture (right foot in sama and the left foot obliquely placed, the left side of waist raised), the gait, slow tempo, and measured steps and paralinguistic features such as low notes, grave, low, and slow intonation and slow tempo suggested her pathetic feelings. Before moving on to the analysis of terrible in the play, the gender issues need a discussion. Mahesh Dattani composed this play keeping females as a center of the play. Overall, the production relates to the anger and love between Nazia and Suhel, Nazia and Ruby and Ruby and Nikhat and reconciliation among them as it does happen in Kalidas' Abhijnanshakuntala. However, Lillette Dubey seems have developed karunarasa (tragic) more than others have. Since the play revolves around the life and times of the actor, Nazia Sahiba, who became a victim of partition. In such tragic events, Nazia lost her sister, lost the love and eventually disconnected from her daughter Ruby. The absence of love and presence of trauma and anger within these relations gave prominence to karunarasa.

\section{Bhayankarasa (Terrible)}

Rape, partition and Zarine's death contributed to the bhayanka rasa (terrible). While Ruby, her daughter born out of rape, demanded why her mother had abandoned her, Nazia describes the curse of partition on her sister and herself in which she was raped, and her sister was murdered (see the Figure 2 below). 


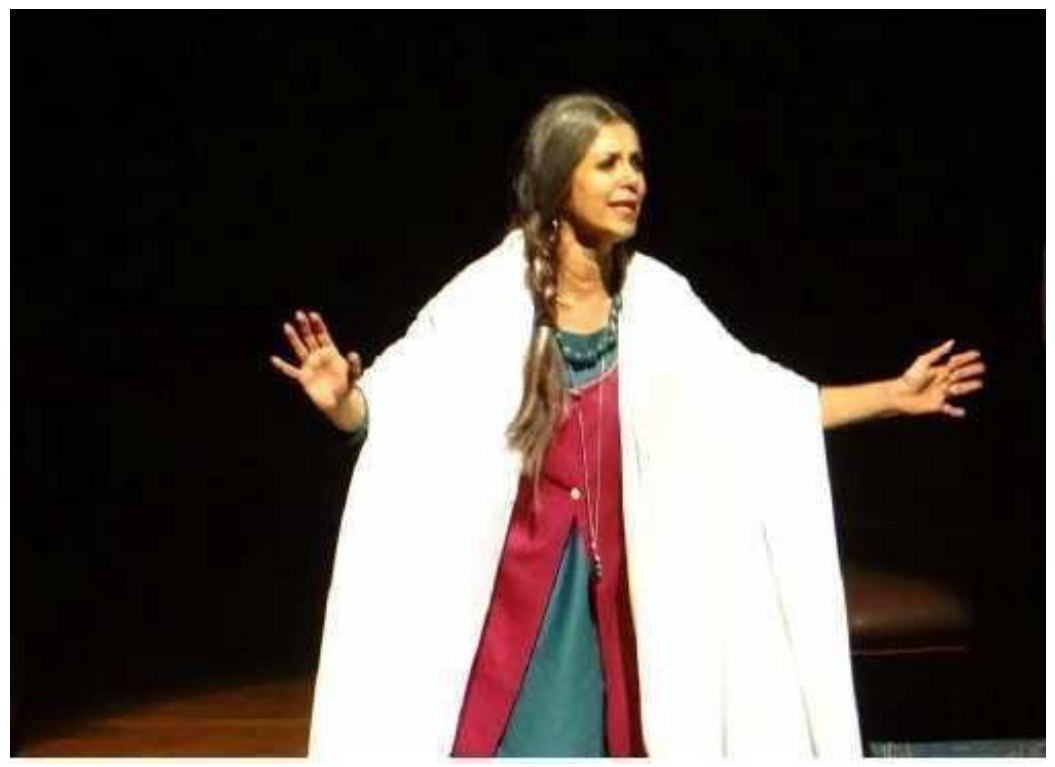

Figure 2: Rape narrative

Glances, gestures and paralinguistic features accompany the painful, fearsome and traumatic monologue. Nazia exhibits these with rakta face (reddened face), glances such as bhayanvita (eyes wide open), vipluta (eyelids tremble then motionless and eyeballs disturbed) and niskramana (eyeballs going out). These glances are supported by gestures such as vikrsta nose (blown lobes), kampana (throbbing of the lips) and kampana gesture with the thighs (raising and lowering the heels repeatedly). Moreover, the use of high notes, excited-high intonation, trembling, change of color (putting pressure on artery) and angry mood (combination of smiling, weeping and sorrow) enhances the feeling of terrible.

\section{Raudrarasa (anger)}

Dattani has presented the angst against partition through different characters. Nazia is angry due to Suhel's passivity during her rape whereas Ruby is annoyed because her mother had abandoned her. Similarly, Ruby's daughter, Nikhat is angry with her mother and wants recognition from her mother. Having considered Nazia's physical manifestation, this section considers examining Sony Razdan, Ruby and Neha Dubey, Nikhat. The antagonism between Nazia and Ruby occurs due to Nazia's rape and Ruby's subsequent abandonment by Nazia. Nazia as a mother does not want to recognize Ruby as her child whereas Ruby questions it and knowingly Ruby calls her 'aunt.' Knowing that Ruby is her daughter, Nazia could not bear her presence which is evident when she uses kuncita glance (contracted eyeballs with bent eyelashes) to show her anger. The "stare" and "glare" at each other could be observed with their manifestation glances such as kruddha (motionless eyelids, drawn up, eyeballs immobile and turned up with knitted eyebrows) and raudri (rough eyeballs, red, raised eyelids are still and eyeballs knitted) which go parallel with eyelid gestures such as unmesa and nimesa (separating the eyelids). 
Nazia's rejection of her mother infuriates her which she manifested with a sankita glance (once moved, once at rest, slightly raised, obliquely open and timid eyeballs), and akampita head gesture (moving the head slowly up and down). If Nazia abandoned Ruby, Ruby neglected Nikhat, her daughter. Nikhat personifies the lost ring ${ }^{\mathrm{xi}}$ as in the Abhinjanshakuntala, and she is employed as a theatrical device in the play. Nikhat reminds Nazia of her youth and is as angry as Ruby toward her mother. She shows her anger with a change of voice (broken and choking voice), kruddha glance (eyelids motionless, drawn up, eyeballs immobile and turned up, eyebrows knitted). She manifests gestures such as kampita head (moving the head quickly and copiously), utksepa eyebrows (raising the eyebrows simultaneously), chinna gesture of chin (two tips very closely meet each other) and udvahi gesture of mouth (the mouth turned up).

The above analysis strongly implies that the three-part definition and rasa-bhava descriptors could assist in understanding the manifestation of micro gestures as well as mental states of the actors. However, a significant shortcoming to this approach lies in the fact that theatre is an ephemeral activity, and therefore, each actor in different scenes produce multiple gestures in micro-moments which remain temporary and to analyze all the characters, and their manifestation of gestures could not be possible within the limited scope of this article. Despite this limitation, this approach allows examining external and internal signs such as gestures, glances, and movements to make meaning. This analysis, then, does what Gantar and Taylor proposed earlier regarding performance delivery.

\section{Discussion}

One of the aims of this article is to examine what Natyashastra can offer regarding production analysis. As mentioned earlier, approaches based on theatre semiotics work well with signs and codes; however, they could not assist in analyzing physical and mental states of the actors, as these models consider the actor's body and mind as separate entities. On the contrary, the Natyashastra establishes the role of bodymind in producing gestures despite Indian actors not trained in the tradition of the treatise which means actor' training methods whether the 'Eastern' or 'Western' prepare them to execute psychophysical processes to enact a character and these processes, congruous with Daboo's (2013) earlier claim, produce precise notation which has been identified by Bharata in the Natyashastra.

The director, Dubey trained with Barry John and familiar with the tenets of the Natyashastra but not trained, allowed actors to 'explore...discover himself/herself.' In her words, 'I did not tell my actors to move from here to there, do this or that, now in this emotion that is not how it is...the actors themselves have to find the feelings and intentions in a scene and what is at stake. Seeing the graph of each character during the entire production and the rise and fall of their sentiments, Dubey acts as a guide to assist actors to perform the characters' feelings (Dubey L. , 2015). Dubey's approach correlates Zarrilli's notion of "absorption." That means actors engage with the character through personal inquiry and internalizing the character. In other words, actors' doing and being 
in character as Zarrilli suggested earlier. Such a journey navigates through psychophysical processes and works on body and mind simultaneously. Neha Dubey responds on this process thus:

How we use our hands, talk, and accents, most of them, fortunately, or unfortunately, belong to an urban milieu and do not belong to the non-urban milieu. They are psychological, expressed physically and as far as I am concerned. I am not trained in the Natyashastra, nor I did display those gestures consciously what you examine here [referring to the analysis above] which I think I might have presented. (Dubey N. , 2015)

It seems evident from the above that body reacts to the mind loaded with emotions. The body's response to emotions occurs due to the neural mechanism as Nair (2015), and Schechner (2015) point out in their study on the Natyashastra. Additionally, the unconscious processes at work create precise gestures, glances and movements as Daboo (2013) maintained in her comment on the embodied presence of the given character.

Through this process, it can be understood and observed that the mind executes physical manifestations and the body reciprocates by producing micro gestures or minimal units of gestures or gestemes, which Pavis argued that could not be analyzed. However, it is difficult to establish that actor training does not play a vital role in these contexts. Even though the issue of actor training needs more practice-based approach as well as analysis of case studies to establish any links with the Natyashastra, this article breaks the notion that actors' gestures cannot be examined with historical, social and cultural layers. This analysis, then, confirms that the Natyashastra can be exercised to examine theatrical performances by keeping sentiments, as its focus by critics not trained the Natyashastra. Additionally, this Natyashastra-based examination could further mean that the terminologies applied here could be employed to investigate different cultural productions. Thus, this article reiterates Nair's emphasis that the Natyashastra has contemporary relevance and 'is equally flexible for redefinitions and reinterpretations' (Nair, The Natyasastra and the Body in Performance : Essays on Indian Theories of Dance and Drama, 2015, p. 5).

The article has outlined the results of the preliminary research on a single case study investigation of actors' gestures; however, the outcomes of this test can be broadened by including the rehearsal process, interviews with musicians, stage and costume designers and even audience analysis using rasabhava concepts.

\section{Funding Disclosure/Acknowledgement}

I would like to thank all the anonymous reviewers of this article for providing their valuable comments and suggestions. 


\section{Endnotes}

i Born in 1958, Dattani's works include Tara (1990), Dance Like a Man (1989); religious communalism (Final Solutions, 1991); homophobia (Bravely Fought the Queen, 1991); the radio play, Do the Needful (1997); child sexual abuse (30 Days in September, 2001); homosexuality (Seven Steps Around the Fire, 1999, and Muggy Night in Mumbai, 1998); consumerism (Big Fat City, 2013), and cancer survivors (Brief Candle, 2009). He is a recipient of the Sahitya Akademy Award.

ii Born in 1953, Dubey's works include Womanly Voices (2005) (Utran by Wajeeda Tabassum, Shishu by Mahashweta Devi and The Music Teacher by Gita Mehta); 30 Days in September (2007) by Mahesh Dattani; Sammy (2009) by Pratap Sharma, and Wedding Album (2009) by Girish Karnad. Her films include Mira Nair's Monsoon Wedding (2001), Karan Johar's Kal Ho Naa Ho (2003), and The Best Exotic Marigold Hotel (2011).

iii Kalidasa's [370-450] Abhinansakuntala is regarded as one of the finest plays in Sanskrit and world literature. The plot of the play is borrowed from the Sanskrit epic, the Mahabharata.

iv See Bannerji (2004: 3807) for violence; Brass (2006) for reasons for communal violence; Menon (2006: 30) and Gauri Viswanath and Salma Malik (2009: 67) for violence against women. Apart from these and other scholarly works on partition, there have been a number of theatrical performances about the Indian partition. For example, the Tamasha Theatre Company's A Tainted Dawn (1997); The Other Side of Silence: Voices from the Partition of India (2000), scripted by B. Gauri and directed by Kirti Jain (2003); Man Mela's production of Umraan Langian Phabaan ( $A$ Lifetime On Tiptoes) (2007); Amita Deepak Jha's A Tryst with Destiny (2012), and Howard Brenton's recent play Drawing the Line (performed 3 December 2013 to 11 January 2014).

${ }^{v}$ Zohra Sehgal (1912-2014) was an Indian actor, choreographer, and dancer and has received many awards, including the Sangeet Natak Akademi, India's highest award for dance, drama, and music.

vi Eco rightly observed, there are many Western aesthetic theories,' they often fail to appreciate the simple fact that 'there are also many Indian aesthetic theories'. See Eco, U. (2005, October). Transcultura Meeting. Transcultura Meeting. Pondicherry.

vii Ithaca College and the Cornell University in New York organized a conference on 'Rasa theory, Practice and Performance' in 2012; however, its focus remained on Richard Schechner's rasaboxes exercises which will eventually aid directors, actors, and choreographers. (Neuerburg-Denver, 2012) (Minnick, 2012) (Nuttal, 2013)

viii Gantar (1996) states that theatre as "a sophisticated rhetorical instrument in which one group of people is delivering messages, occasionally distracted by unwanted intrusions of noise, to another group of people" (Gantar, 1996, p. 540). Furthermore, he notes that theatre is "subject to the performer's emotions and the spectator's prejudices" (Gantar, 1996, p. 544). He also suggests that theatre analysis should investigate manifestations of actors' emotions as well as spectators' reception of actors' bodily manifestations. He further states, "today, theatre scholars are often more interested in the actor's gestures or delivery than in the literary analysis of the text" (Gantar, 1996, p. 538). Gantar's observations provide a case for a more structured approach for decoding psychophysical acting rather than play-texts alone.

${ }^{\text {ix }}$ Interestingly, David Mason argues that Schechner has 'misunderstood' the term rasa (Mason, 2006). 


\footnotetext{
${ }^{x}$ All the subsequent pictures in this case study have been provided by Lillete Dubey and Prime Time Theatre Company and am thankful for them for this support.

${ }^{x i}$ Dubey comments, "It is an echo of Kalidasa's Shakuntala. She [Nikhat] is the ring. It is the beautiful the way he (Mahesh Dattani) [...] an object which she personified. It is an object just a ring and everything comes back. Similarly, it is her and now her spitting image of herself so he has taken an object and personified it". Interviewed by author, "Lillete Dubey (Director-Actor of Where Did I Leave My Purdah)" (Mumbai, 2015).Nikhat is Nazia's daughter in the play and in real life too, Lillete Dubey (Nazia) is mother of Neha Dubey (Nikhat). Thus, in that sense Neha was reflecting Lillete's image thus, seen as a ring which reminds Nazia of her young age when she was raped which she wished to wipe out from her memory deliberately.
}

\section{References}

Barlingay, S. S. (1981). "What Did Bharata Mean by Rasa?". Indian Philosophical Quarterly, 8(4), 433-456.

Committeri, G., \& Chiara, F. (2016). Body Presence and Extra-Personal Space Perception. In C. Falletti, Gabriele Sofia, \& V. Jacono, Theatre and Cognitive Neuroscience (S. 23-34). London: Bloomsbury Methuen.

Daboo, J. (2013). Afterword: Dialogue and Paradox. In P. Zarrilli, J. Daboo, \& R. Loukes, Acting: Psychophysical Phenomenon and Process: Intercultural and Interdisciplinary Perspective (S. 256-61). London: Palgrave Macmillan.

Dhavan, R. K., \& Reddy, V. K. (2004). Flowering of Indian English Drama. New Delhi: Prestige.

Dubey, L. (31. May 2015). Interview with the Director . (M. Chavda, Interviewer)

Dubey, N. (27. October 2015). Interview with Dubeys. (M. Chavda, Interviewer)

Hogan, P. (2003). Rasa Theory and Dharma Theory: The Home and the World to Bandit Queen. Quarterly Review of Film and Video, 20, 37-52.

Madhavan, A. (2010). Kudiyattam: Theatre and the Actor's Consciousness. Amsterdam: Rodopi.

Mason, D. (2006). Rasa, 'Rasaesthetics' and Dramatic Theory as Performance Packaging. Theatre Research International, 1, 69-82.

Minnick, M. (24. March 2012). Rasa: In Theory, Practice and Performance Symposium. Von https://www.ithaca.edu: https://www.ithaca.edu/hs/news/rasa:-in-theory,-practice-andperformance-symposium--march-31-april-1,-2012-23015/ abgerufen

Mitra, R. (2015). Akram Khan: Dancing New Interculturalism. London: Palgrave Macmillan.

Nair, S. (2012). Rasa Theory and Neural Mechanism. New Zealand Online Journal of Interdisciplinary Studies, 1(2), 1-27.

Nair, S. (2015). The Natyasastra and the Body in Performance : Essays on Indian Theories of Dance and Drama. Jefferson, NC: McFarland and Company.

Neuerburg-Denver, U. (24. March 2012). Rasa: In Theory, Practice and Performance Symposium. Von https://www.ithaca.edu: https://www.ithaca.edu/hs/news/rasa:-in-theory,-practiceand-performance-symposium--march-31-april-1,-2012-23015/ abgerufen 
Nuttal, D. (2013). Rhythm Embodied: Training Rasa in Hindustani Table. Studies in South Asian Film and Media, 5(1), 69-79.

Patel, C. (2015). The Taste of British Asian Theatre Performance. USA: Lulu Publishers.

Schechner, R. (2001). Rasaesthetics. The Drama Review, 45(3), 27-50.

Schechner, R. (2005). Performance Theory. New York: Routledge.

Schwartz, S. (2008). Rasa : Performing the Divine in India. Banaras: Motilal Banarsidass Publication.

Srinivas, C. (2014). Significance of Rasa and Abhinaya Techniques in Bharata's Natyashastra. IOSR Journal of Humanities and Social Sciences, 14(5), 25-29.

Taneja, N. (25. March 2009). Bollywood Comes Calling for Sid Makkar. Von Hindustan Times www.hindustantimes.com: http://www.hindustantimes.com/india/bollywood-comescalling-for-sid-makkar/story-8bSVGmocVXoFWM2jNMDPKP.html. abgerufen

Zarrilli, P. (200o). Kathakali Dance-Drama: Where Gods and Demons Come to Play. London: Routledge.

Zarrilli, P. (2006). Imperial Theatre: Pleasure, Power and Aesthetics. In C. F. Sorgenfrei, T. Nellhaus, T. Underiner, \& B. McConachie, Theatre Histories: An Introduction (S. 99-148). New York: Routledge.

Zarrilli, P. (2011). Psychophysical Approaches and Practices in India: Embodying Processes and States of 'Being-Doing. New Theatre Quarterly, 27(3), 244-71.

Zarrilli, P. (2013). Introduction: Acting as Psychophysical Phenomenon and Process. In P. Zarrilli, J. Daboo, \& R. Loukes, Acting: Psychophysical Phenomenon and Process: Intercultural and Interdisciplinary Perspective (S. 1-50). London: Palgrave Macmillan.

Mrunal Chavda lectures as an Assistant Professor in English Literature at Institute of Language Studies and Applied Social Sciences. His research examines British South Asian theatre and Contemporary Indian theatre practices and production analysis by employing Bharata's Natyashastra. He also investigates Bollywood, Gujarati cinema, Gujarati dance form and literary aspects of South African Gujarati diaspora. He has published peerreviewed original research articles in South Asian Popular Culture, Dance Chronicle and Shahitya Akademi's journal Shabdshrusti. 